\title{
Polymorphism and expression of the tumor necrosis factor receptor II gene in cows infected with the bovine leukemia virus
}

\author{
A. Stachura, P. Brym, B. Bojarojć-Nosowicz, E. Kaczmarczyk \\ Department of Animal Genetics, Faculty of Animal Bioengineering, \\ University of Warmia and Mazury in Olsztyn, Oczapowskiego 5, 10-719 Olsztyn, Poland
}

\begin{abstract}
A single $\mathrm{T}>\mathrm{C}$ nucleotide polymorphism (rs42686850) of bovine tumor necrosis factor receptor type II gene (TNF-RII) is located within a sequence with allele-specific affinity to bind E2F transcription factors, considered pivotal in the regulation of cell cycle and cell proliferation. The objective of the study was to determine the effect of this SNP and BLV infection on the TNF-RII gene expression at the mRNA and protein levels in peripheral blood mononuclear cells (PBMC). We noted that analyzed TNF-RII gene polymorphism influenced the expression of the TNF-RII gene at the mRNA level but only in BLV-positive cows. Concurrently, no statistically significant association was found between gene polymorphism and TNF-RII expression at the protein level. However, we found a significant effect of BLV infection status on the amount of TNF-RII mRNA and the percentage of PBMC expressing TNF-RII. These results show an unclear effect of considered $\mathrm{T}>\mathrm{C}$ polymorphism on TNF-RII gene expression in bovine leukocytes and they suggest the involvement of BLV in modifying the TNF-RII expression in BLV-infected cows potentially implying the EBL (Enzootic Bovine Leukosis) associated pathogenesis.
\end{abstract}

Key words: TNF-RII gene, polymorphism, gene expression, BLV, EBL

\section{Introduction}

It is believed that mutations in the genes encoding cytokines and their receptors can cause differences in the individual's immune response and play an important role in susceptibility/resistance to infectious diseases (Nishimura et al. 2000, Tsukasaki et al. 2001). TNF-RII gene polymorphism in the first intron at position 16534 results from $\mathrm{T}>\mathrm{C}$ substitution (rs42686850) (Stachura et al. 2013) and includes a se- quence with an allele-specific affinity to bind E2F transcription factors, considered pivotal in the regulation of cell cycle and cell proliferation (Phillips et al. 1999, Müller and Helin 2000). The first intron is known to regulate the expression of some genes, and mutations in this region can influence the level of their expression (Tsukada et al. 2006, Yudin et al. 2006, Muráni et al. 2009). Studies on enzootic bovine leukosis (EBL) demonstrated that a significant increase in TNF-RII expression, (but not in TNF-RI),

Correspondence to: B. Bojarojć-Nosowicz, e-mail: b.bojarojc@uwm.edu.pl, tel.: +48 895233844 
could contribute to the pathogenesis of EBL (Konnai et al. 2006). TNF-RII has also been suggested as a factor stimulating cell proliferation and inhibiting apoptosis (Yang et al. 2002, Cui et al. 2008). Nevertheless, reasons for changes in TNF-RII expression in peripheral blood mononuclear cells (PBMC) sampled from animals infected with BLV and during the progression of EBL have not been explained.

The objective of the study was to determine the influence of $16534 \mathrm{~T}>\mathrm{C}$ TNF-RII gene polymorphism and BLV infection on the TNF-RII gene expression measured on mRNA and protein levels.

\section{Materials and Methods}

The study was performed on Polish Holstein-Friesian cows aged 4-8 years from four BLV-infected herds located in north-eastern and central Poland. The number of animals used in the study varied depending on the type of analyzed factor, and is specified in the figures and tables presenting findings. Blood samples were analyzed for hematology parameters (Sysmex SF3000 hematology analyzer - SYSMEX Corporation, Japan), used further to group BLV-positive cows into those with aleukemic (AL) $\left(<12 \times 10^{9} / \mathrm{L}\right.$ leukocytes and $<8 \times 10^{9} / \mathrm{L}$ lymphocytes, respectively) and persistent lymphocytosis (PL) $\left(>12 \times 10^{9} / \mathrm{L}\right.$ leukocytes and $>8 \times 10^{9} / \mathrm{L}$ lymphocytes) forms of the disease. The study was approved by the local ethics committee of University of Warmia and Mazury in Olsztyn, Poland (no. 59/2008/N/T).

\section{Genotyping of TNF-RII gene polymorphism}

We used a PCR-RFLP/ApaLI method for genotyping of $\mathrm{T}>\mathrm{C}(\mathrm{rs} 42686850)$ polymorphism within bovine TNF-RII gene. Primers for PCR with sequences F-5'TGGTGGCCTCGGTCACAGAGA3' and R-5'CCCTGGGCGCTGACCCTTTG3' were designed and the amplification program consisted of initial DNA denaturation $\left(94^{\circ} \mathrm{C} / 3 \mathrm{~min}\right), 35$ cycles $\left(94 \mathrm{C} / 30 \mathrm{~s}, 69^{\circ} \mathrm{C} / 30 \mathrm{~s}, 72^{\circ} \mathrm{C} / 30 \mathrm{~s}\right)$ and final synthesis $\left(72^{\circ} \mathrm{C} / 5 \mathrm{~min}\right)$. The ApaLI enzyme detects the 5'G $\downarrow$ TGCAC3' sequence (allele T) and digests the amplified $640 \mathrm{bp}$ amplicon into two fragments: $441 \mathrm{bp}$ and $199 \mathrm{bp}$.

\section{Diagnosis of infection with the bovine leukemia virus}

BLV infections were diagnosed by the nested PCR method (Markiewicz et al. 2003) and immuno- fluorescence method (IMF) (Kaczmarczyk et al. 2008). Animals tested as positive for BLV by both methods were used in further experiments.

\section{Expression of the TNF-RII gene at the mRNA level}

Total RNA was isolated from peripheral blood sampled into test tubes containing a stabilizer (PAXgene Blood RNA Tube - PreAnalytiX, Switzerland), using a PAXgene Blood RNA Kit and the procedure recommended by the manufacturer (PreAnalytiX, Switzerland). Only high quality samples characterized by RIN (RNA Integrity Number) $>8.5,28 \mathrm{~s} / 18 \mathrm{~s}>1.6$ and $A_{260} / A_{280}>2.0$ were used in the TNF-RII expression measurements. cDNA was synthesized with $1 \mu \mathrm{g}$ total RNA, oligo-dT(20) and the Transcriptor High Fidelity cDNA Synthesis Kit (Roche, Germany) in accordance with the manufacturer's instructions.

Two step reverse transcription-quantitative PCR (RT-qPCR) was performed with the use of LightCycler $^{\circledR} 480$ II (Roche, Germany), PCR primers specified in table 1 and LightCycler ${ }^{\circledR} 480$ SYBR Green I Master kit in accordance with the manufacturer's instructions (Roche, Germany). The cycling conditions were as follows: pre-incubation at $95^{\circ} \mathrm{C}$ for $3 \mathrm{~min}$ followed by 45 cycles with each cycle including $95^{\circ} \mathrm{C}$ for $10 \mathrm{~s}$, annealing temperature for $10 \mathrm{~s}$ and elongation at $72^{\circ} \mathrm{C}$ for $10 \mathrm{~s}$. The RT-qPCR assays were performed in two replicates for each sample target gene and endogenous controls, and in three replicates for negative control (no template control). The amplicon specificity was confirmed based on the melting curve analysis, $2 \%$ agarose gel electrophoresis and DNA sequencing. Reference genes RPLP0 (Ribosomal Protein, Large, P0) and B2M (Beta-2 Microglobulin) were used to normalize the expression levels according to Brym et al. (2013). The reaction efficiency (E) for each of the three pairs of primers was calculated based on the standard curve of 7-point serial dilutions of pooled cDNA samples used in the experiment (Table 1). The quantification cycle $(\mathrm{Cq})$ was automatically determined by the LightCycler ${ }^{\circledR} 480$ SW 1.5 software with default parameters using the second derivative maximum method (Rasmussen 2001, Roche, Germany).

\section{Expression of the TNF-RII gene at the protein level}

The expression of the TNF-RII gene in PBMC was determined using the IMF method. PBMC were prepared for immunolabeling as published previously (Kaczmarczyk et al. 2004). The TNF-RII epitope was 
Table 1. RT-qPCR primers and amplification conditions.

\begin{tabular}{|c|c|c|c|c|c|c|c|}
\hline Gene & PCR primers $\left(5^{\prime}-3^{\prime}\right)$ (forward/reverse ) & $\begin{array}{c}\mathrm{T}_{\mathrm{a}} \\
\left({ }^{\circ} \mathrm{C}\right)\end{array}$ & $\begin{array}{c}\mathrm{T}_{\mathrm{m}} \\
\left({ }^{\circ} \mathrm{C}\right)\end{array}$ & $\begin{array}{l}\text { Amplicon } \\
\text { size (bp) }\end{array}$ & $\mathrm{E}$ & Error & $\begin{array}{l}\text { Accession } \\
\text { no. / reference }\end{array}$ \\
\hline $\begin{array}{l}\text { TNF-RII } \\
\text { target }\end{array}$ & $\begin{array}{l}\text { F-CTCTTCCCATTGAACTGATTGTGG } \\
\text { R-GGCACCTTGGCATCTCCTTG }\end{array}$ & 62,0 & 82,7 & 127 & 1,98 & 0,0132 & NM_001040490 \\
\hline $\begin{array}{l}\mathrm{RPLP} 0 \\
\text { reference }\end{array}$ & $\begin{array}{l}\text { F-CAACCCTGAAGTGCTTGACAT } \\
\text { R-AGGCAGATGGATCAGCCA }\end{array}$ & 58,0 & 86,3 & 227 & 1,97 & 0,0121 & $\begin{array}{l}\text { NM_001012682 } \\
\text { / Brym et al. } 2013\end{array}$ \\
\hline $\begin{array}{l}\mathrm{B} 2 \mathrm{M} \\
\text { reference }\end{array}$ & $\begin{array}{l}\text { F-AGCAAGGATCAGTACAGCTGCCG } \\
\text { R-ATGTTCAAATCTCGATGGTGCTGCT }\end{array}$ & 58,0 & 82,0 & 105 & 1,93 & 0,0088 & $\begin{array}{l}\text { NM_173893 / } \\
\text { Brym et al. } 2013\end{array}$ \\
\hline
\end{tabular}

$\mathrm{T}_{\mathrm{a}}$ - annealing temperature $\left[{ }^{\circ} \mathrm{C}\right] ; \mathrm{T}_{\mathrm{m}}-$ melting temperature $\left[{ }^{\circ} \mathrm{C}\right]$; bp - base pair; $\mathrm{E}-\mathrm{qPCR}$ efficiency

identified using rabbit anti-human TNF-RII polyclonal IgG antibody (H-202) (working dilution 0.5 $\mu \mathrm{g} / 50 \mu \mathrm{L}$ ) (Santa Cruz Biotechnology) and goat anti-rabbit IgG $(\mathrm{H}+\mathrm{L})$ secondary antibody conjugated to FITC (working dilution $1.0 \mu \mathrm{g} / 50 \mu \mathrm{L}$ ) (Invitrogen, USA). The specificity of H-202 antibody against bovine TNF-RII epitope was confirmed by Ikeda et al. (2005). The same protocol was used for controls, but no primary antibodies were added. Smears were analyzed under a fluorescence microscope (Axiolab-Zeiss, Germany), at $1000 \mathrm{x}$ magnification. Six hundred cells were registered per smear, and the percentage of TNF-RII+ cells was calculated.

\section{Statistical analysis}

The levels of the TNF-RII gene transcript were analyzed using the Relative Expression Software Tool 2009 (REST 2009) (Qiagen, USA), and the significance of differences between the groups was verified by the Pair-Wise Fixed Reallocation Randomization Test (Pfaffl et al. 2002). In addition, a nonparametric Kruskal-Wallis ANOVA for ranks, a median test for the analysis of the percentage of TNF-RII+ cells (for non-normal data distribution) and multiple comparisons in a nonparametric test at $\mathrm{p}<0.05$ and $\mathrm{p}<0.01$ were used to verify the significance of differences between animal groups. Data were processed using the STATISTICA 9.0 software package (StatSoft Inc., USA).

\section{Results}

\section{The effect of $\mathbf{T}>\mathbf{C}$ nucleotide polymorphism (rs42686850) on TNF-RII expression at the mRNA and protein levels}

In order to analyze the effect of $\mathrm{T}>\mathrm{C}$ nucleotide polymorphism on TNF-RII expression, the animals of three genotypes $(\mathrm{T} / \mathrm{T}, \mathrm{T} / \mathrm{C}$ and $\mathrm{C} / \mathrm{C})$ were identified within BLV-positive (divided for AL and PL subgroups respectively) and BLV-negative cows with the use of PCR-RFLP genotyping (Fig. 1).

The relationship between the polymorphism of the TNF-RII gene and its expression at the mRNA level revealed significant differences in BLV-positive cows (Fig. 2A). In cows with the T/C genotype the mRNA level was almost $50 \%$ lower than that in cows with the $\mathrm{T} / \mathrm{T}$ genotype $(\mathrm{p}<0.05)$. The TNF-RII gene expression in $\mathrm{C} / \mathrm{C}$ homozygotes was similar to that noted in the control animals with the $\mathrm{T} / \mathrm{T}$ genotype. Differences in the amount of transcript in BLV-negative cows with different TNF-RII genotypes were small and statistically insignificant (Fig. 2B).

The analysis of relationships between TNF-RII gene polymorphism and the size of the PBMC subpopulation expressing the TNF-RII protein demonstrated statistically insignificant differences in the percentage of TNF-RII+ cells between cows with different TNF-RII genotypes, both BLV-positive and BLV-negative (Table 2). However, the percentage of PBMCs expressing TNF-RII protein was higher in all BLV-positive cows when compared to BLV-negative cows. Moreover, in BLV-positive $\mathrm{T} / \mathrm{C}$ heterozygotes the percentage of TNF-RII+ cells was clearly higher than in $\mathrm{T} / \mathrm{T}$ homozygotes $(\mathrm{p}=0.16)$.

\section{The effect of BLV infection and disease stadium on TNF-RII expression}

Statistical analysis demonstrated significantly lower amounts of mRNA TNF-RII in BLV-positive animals as compared to BLV-negative cows $(p<0.001)$. Differences were found both for BLV+AL and BLV+PL animals (Fig. 3).

The analysis of the interaction of both factors (TNF-RII gene polymorphism and BLV infection) on the expression of the TNF-RII gene (Fig. 4) revealed statistically significant differences between BLV-positive cows with the $\mathrm{T} / \mathrm{C}$ genotype and the control group (T/T, BLV-). In BLV+AL cows with 


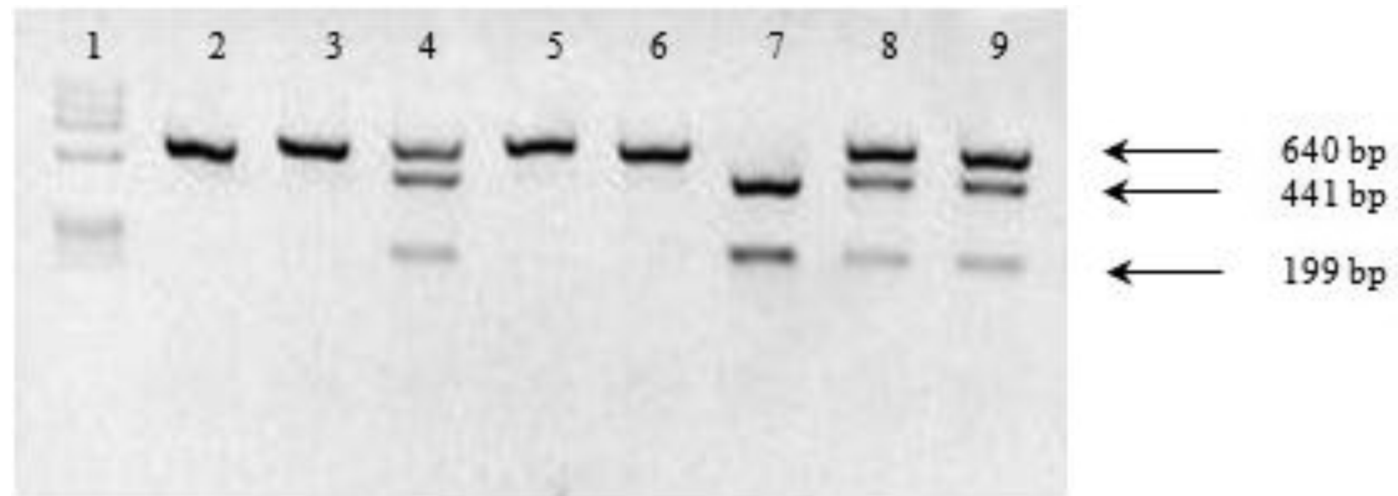

Fig. 1. PCR-RFLP/ApaLI genotyping of T $>C$ polymorphism (rs42686850) within bovine TNF-RII gene. Line 1- PhiX 174/HaeIII, molecular marker; Line 2 - undigested PCR product (640 bp); Lines: 3, 5, 6 - C/C genotype (640 bp); Lines: 4, 8, 9 - T/C genotype (640 pz, 441pz, 199 pz); Line 7 - T/T genotype (441 pz, 199 pz).
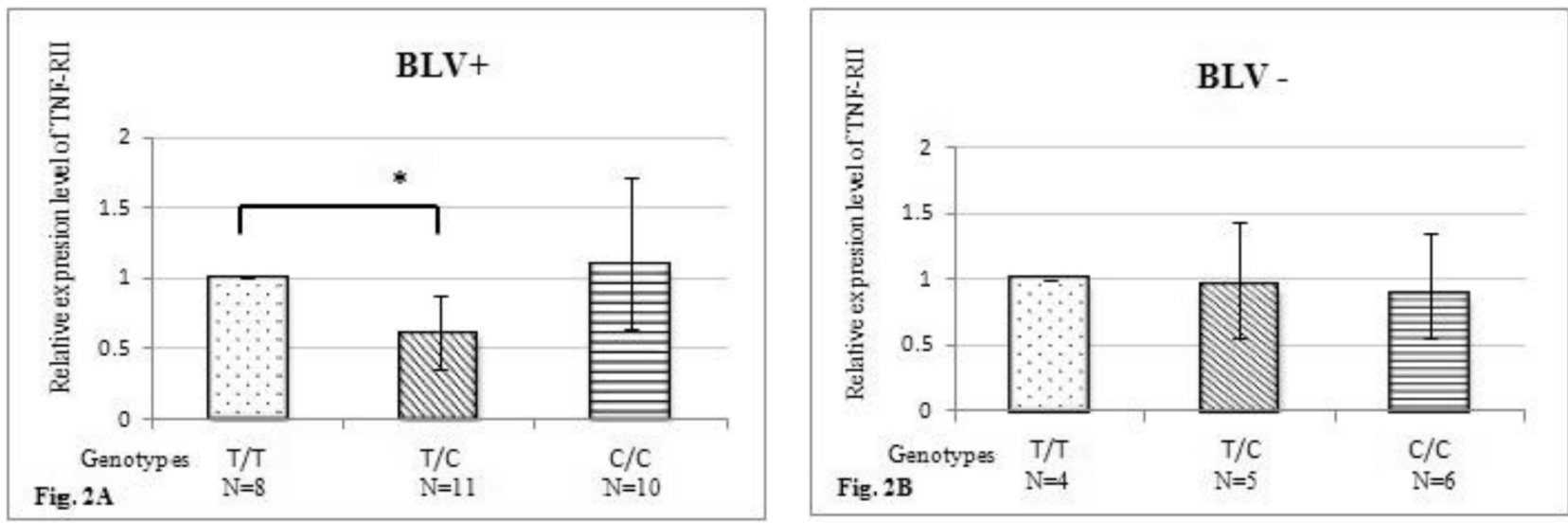

Fig. 2. A) Relative levels of TNF-RII mRNAs in BLV-positive cows with different TNF-RII genotypes. B) Relative levels of TNF-RII mRNAs in BLV-negative cows with different TNF-RII genotypes. Results are presented as the normalized ratio of the gene expression level in a study group to the gene expression level in the control group $\pm \mathrm{SEM}$ (standard error of the mean). $\mathrm{T} / \mathrm{T}$ homozygotic cows were used as the control. * statistically significant differences at $\mathrm{p}<0.05$.

Table 2. Percentage of PBMCs expressing TNF-RII protein in BLV-positive and BLV-negative cows with different genotypes.

\begin{tabular}{ccccc}
\hline \multirow{2}{*}{ Groups of cows } & & \multicolumn{2}{c}{ TNF-RII+ cells (\%) } \\
\cline { 3 - 4 } & TNF-RII genotypes & $\mathrm{N}$ & $\bar{x}$ & *SEM \\
\hline \multirow{3}{*}{ BLV+ } & $\mathrm{T} / \mathrm{T}$ & 19 & 2,69 & 0,20 \\
& $\mathrm{~T} / \mathrm{C}$ & 28 & 3,28 & 0,43 \\
$\mathrm{C} / \mathrm{C}$ & 23 & 2,75 & 0,31 \\
\hline \multirow{2}{*}{$\mathrm{BLV}-$} & $\mathrm{T} / \mathrm{T}$ & 11 & 2,03 & 0,24 \\
& $\mathrm{~T} / \mathrm{C}$ & 18 & 2,52 & 0,26 \\
& $\mathrm{C} / \mathrm{C}$ & 18 & 2,25 & 0,17 \\
\hline
\end{tabular}

* SEM - standard error of the mean

the $\mathrm{T} / \mathrm{C}$ genotype the level of mRNA was three-fold lower than in the control animals $(\mathrm{p}<0.01)$, and even lower values were noted in BLV+PL cows $(\mathrm{p}<0.001)$. Differences in the amount of the transcript were also found between other TNF-RII genotypes of BLV+ cows and the control group (T/T, BLV-), but they were not statistically significant (Fig. 4).
The analysis of the TNF-RII protein expression levels demonstrated differences between percentages of TNF-RII+ cells in BLV-positive and BLV-negative cows (Table 3). Statistically significant differences were found between BLV+PL and BLV- animals $(p<0.001)$. The percentage of TNF-RII+ cells in BLV+PL cows was significantly higher than in 


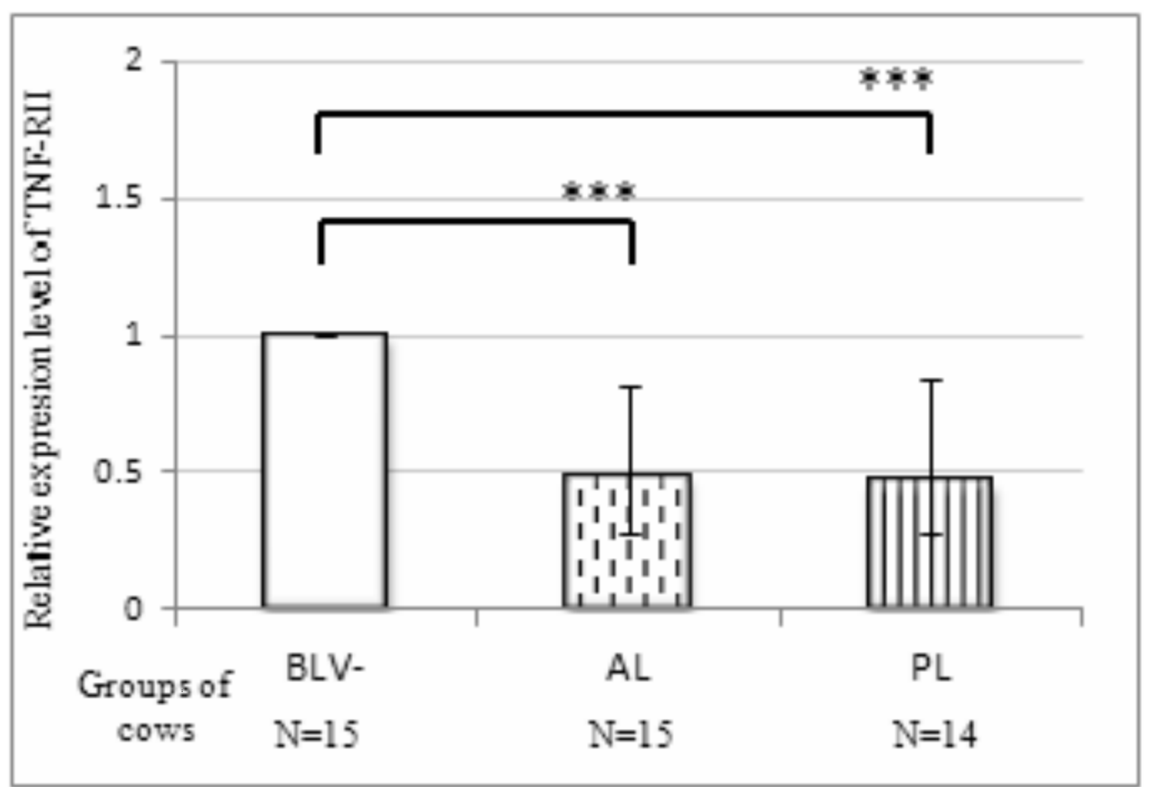

Fig. 3. Relative levels of TNF-RII gene expression measured by RT-qPCR in cows differing with BLV infection and health status. Results are presented as the normalized ratio of the gene expression level in a study group to the gene expression level in the control group \pm SEM (standard error of the mean). BLV-negative animals cows were used as the control. *** statistically significant differences at $\mathrm{p}<0.001$.



Fig. 4. Relative level of TNF-RII gene expression in BLV-positive and BLV-negative cows with different genotypes. Results are presented as the ratio of the gene expression level in a study group to the gene expression level in the control group \pm SEM. BLV-negative T/T homozygotic cows were used as the control. *** statistically significant differences at $\mathrm{p}<0.001 ; * *$ statistically significant differences at $\mathrm{p}<0.01$.

Table 3. Percentage of TNF-RII+ cells in BLV-positive and BLV-negative cows.

\begin{tabular}{cccc}
\hline \multirow{2}{*}{ Groups of cows } & $\mathrm{N}$ & $\bar{x}$ & TNF-RII+cells (\%) \\
\cline { 3 - 4 } & & $2,43^{\mathrm{A}}$ & SEM \\
\hline BLV+AL & 56 & $5,00^{\mathrm{AB}}$ & 0,15 \\
BLV+PL & 14 & $2,25^{\mathrm{B}}$ & 0,60 \\
BLV- & 47 & 0,13 \\
\hline
\end{tabular}

Mean values followed by the same capital letter A or B are significantly different at $\mathrm{p}<0.001$ 
$\mathrm{BLV}+\mathrm{AL}$ or BLV- animals (Table 3), while differences between uninfected cows and BLV+AL were small and statistically insignificant.

\section{Discussion}

The study revealed a relationship between TNF-RII gene polymorphism at the position 16534 $\mathrm{T}>\mathrm{C}$ in the first intron and the TNF-RII gene expression at the mRNA level, but only in cows infected with BLV. This was also confirmed by the interaction effect of TNF-RII genotype and infection with BLV on the amount of the TNF-RII transcript, suggesting a modifying influence of BLV on the TNF-RII gene expression at the mRNA level.

Previous studies have demonstrated a significant role of the TNF- $\alpha /$ TNF-R signaling pathway in BLV infection and EBL progression (Ikeda et al. 2005, Konnai et al. 2005). Konnai et al. (2006) reported higher TNF- $\alpha$ mRNA levels and higher surface expression of TNF- $\alpha$ in spontaneously proliferating PBMCs isolated from BLV-positive cows as compared to healthy cows. Konnai et al. (2005) also found a significantly higher level of the TNF-RII transcript in PBMCs isolated from cows with subclinical forms of EBL (AL or PL) than in cows uninfected with BLV. In contrast, in our study, the expression of this gene at the mRNA level was found substantially lower in $\mathrm{BLV}+\mathrm{AL}$ and $\mathrm{BLV}+\mathrm{PL}$ cows than in BLV-negative cows. These opposite results could be attributed to different methodological approaches used. The accurate normalization of the expression level for the analyzed gene is a critical step of RT-qPCR (Bustin et al. 2009). Konnai et al. (2005) used a single $\beta$-actin gene (ACTB) as a reference gene for normalization purposes. However, recent studies demonstrated that ACTB, because of its low expression stability due to viral infection, is an unsuitable reference gene for RT-qPCR normalization in leukocytes of cattle infected by viral agents (Anstaett et al. 2010, Spalenza et al. 2011, Brym et al. 2013). The requirement of at least two reference genes for proper normalization was recommended (Bustin et al. 2009) and Brym et al. (2013) suggested that UCHL5 and RPLP0 or RPLP0 and $\mathrm{B} 2 \mathrm{M}$ could be used for the proper normalization of expression levels in peripheral blood cells from cows infected with BLV.

In our studies TNF-RII protein expression in PBMCs was reflected in a significantly higher percentage of TNF-RII+ cells in BLV+PL cows as compared to BLV-negative cows. In cows with PL, more than 2-fold higher percentage of TNF-RII+ cells was noted in comparison to the non-infected animals. Previously, Ikeda et al. (2005) detected the TNF-RII re- ceptor only on neoplastic cells from cows with LS. The TNF-RII receptor was suggested to be the major factor responsible for the proliferative and anti-apoptotic effect of TNF- $\alpha$ (Tartaglia et al. 1993, Aspalter et al. 2003). Furthermore, we observed that TNF-RII expression at the protein level had a different pattern than the expression at the mRNA level, which was particularly clear in BLV+PL animals. Such enigmatic inconsistencies between the amount and the pattern of changes at the transcript and protein levels have already been reported (Tian et al. 2004, Stark et al. 2006, Sarro et al. 2010) and it is also known that viruses can influence the amount of mRNA and protein in host cells and modify the synthesis and metabolism of these molecules or influence their stability (Bolinger et al. 2010, Polakowski et al. 2011, Liu et al. 2012). Mechanisms used by BLV interfering with a multistage process of host gene expression are still poorly investigated and require further research.

Our results show the unclear effect of considered $\mathrm{T}>\mathrm{C}$ polymorphism on TNF-RII gene expression in bovine leukocytes and they suggest the involvement of BLV in modifying the TNF-RII expression in BLV-infected cows potentially implying the EBL-associated pathogenesis.

\section{Acknowledgements}

This work was supported by the Polish Ministry of Science and Higher Education, grants NN308249136 and NN311320735.

\section{References}

Anstaett OL, Brownlie J, Collins ME, Thomas CJ (2010) Validation of endogenous reference genes for RT-qPCR normalisation in bovine lymphoid cells (BL-3) infected with Bovine Viral Diarrhoea Virus (BVDV). Vet Immunol Immunopathol 137: 201-207.

Aspalter RM, Eibl MM, Wolf HM (2003) Regulation of TCR-mediated $\mathrm{T}$ cell activation by TNF-RII. J Leukoc Biol 74: 572-582.

Bolinger C, Sharma A, Singh D, Yu L, Boris-Lawrie K (2010) RNA helicase A modulates translation of HIV-1 and infectivity of progeny virions. Nucleic Acids Res 38: 1686-1696.

Brym P, Ruść A, Kamiński S (2013) Evaluation of reference genes for qRT-PCR gene expression studies in whole blood samples from healthy and leukemia-virus infected cattle. Vet Immunol Immunopathol 153: 302-307.

Bustin SA, Benes V, Garson JA, Hellemans J, Huggett J, Kubista M, Mueller R, Nolan T, Pfaffl MW, Shipley GL, Vandesompele J, Wittwer CT (2009) The MIQE guidelines: minimum information for publication of quantitative real-time PCR experiments. Clin Chem 55: 611-622. 
Cui LF, Guo XJ, Wei J, Liu FF, Fan Y, Lang RG, Gu F, Zhang XM, Fu L (2008) Overexpression of TNF-alpha and TNFRII in invasive micropapillary carcinoma of the breast: clinicopathological correlations. Histopathology 53: 381-388.

Ikeda M, Konnai S, Onuma M, Ishiguro N, Goryo M, Okada $\mathrm{K}$ (2005) Immunohistochemical analysis of expression patterns of tumor necrosis factor receptors on lymphoma cells in enzootic bovine leukosis. J Vet Med Sci 67: 425-432.

Kaczmarczyk E, Bojarojć-Nosowicz B, Fiedorowicz A, Demianowicz W (2004) Polymorphism of blood leukocyte acid phosphatase and the profile of peripheral blood lymphocytes in the first of lactation trimester of cows naturally-infected with bovine leukaemia virus. Archiv Tierzucht 47: 415-430.

Kaczmarczyk E, Bojarojć-Nosowicz B, Cybulska O (2008) Comparative analysis of an ELISA and fluorescent antibody test for the diagnosis of Bovine Leukaemia Virus infection in cattle. Bull Vet Inst Pulawy 52: 19-22.

Konnai S, Usui T, Ikeda M, Kohara J, Hirata T, Okada K, Ohashi K, Onuma M (2005) Imbalance of tumor necrosis factor receptors during progression in bovine leukemia virus infection. Virology 339: 239-248.

Konnai S, Usui T, Ikeda M, Kohara J, Hirata T, Okada K, Ohashi K, Onuma M (2006) Tumor necrosis factor-alpha up-regulation in spontaneously proliferating cells derived from bovine leukemia virus-infected cattle. Arch Virol 151: 347-360.

Liu Y, Tong Z, Li T, Chen Q, Zhuo L, Li W, Wu RC, Yu $\mathrm{C}$ (2012) Hepatitis B virus $X$ protein stabilizes amplified in breast cancer 1 protein and cooperates with it to promote human hepatocellular carcinoma cell invasiveness. Hepatology 56: 1015-1024.

Markiewicz L, Rułka J, Kamiński S (2003) Detection of BLV provirus in different cells by nested-PCR. Bull Vet Inst Puławy 47: 325-331.

Muller H, Helin K (2000) The E2F transcription factors: key regulators of cell proliferation. Biochim Biophys Acta 1470: M1-M12.

Murhni E, Ponsuksili S, Seyfert HM, Shi X, Wimmers $K$ (2009) Dual effect of a single nucleotide polymorphism in the first intron of the porcine secreted phosphoprotein 1 gene: allele-specific binding of C/EBP beta and activation of aberrant splicing. BMC Mol Biol 10: 96.

Nishimura M, Maeda M, Matsuoka M, Mine H, Saji H, Matsui M, Kuroda Y, Kawakami H, Uchiyama T (2000) Tumor necrosis factor, tumor necrosis factor receptors type 1 and 2, lymphotoxin-alpha, and HLA-DRB1 gene polymorphisms in human T-cell lymphotropic virus type I associated myelopathy. Hum Immunol 61: 1262-1269.

Pfaffl MW, Horgan GW, Dempfle L (2002) Relative expression software tool (REST) for group-wise comparison and statistical analysis of relative expression results in real-time PCR. Nucleic Acids Res 30: e36.

Phillips AC, Ernst MK, Bates S, Rice NR, Vousden KH (1999) E2F-1 potentiates cell death by blocking antiapoptotic signaling pathways. Mol Cell 4: 771-781.

Polakowski N, Han H, Lemasson I (2011) Direct inhibition of RNAse T2 expression by the HTLV-1 viral protein Tax. Viruses 3: 1485-1500.
Rasmussen R (2001) Quantification on the LightCycler. In: Meuer S, Wittwer C, Nakagawara K (eds) Rapid cycle real-time PCR, methods and applications. Springer Press, Heidelberg, pp 21-34.

Sarro SM, Unruh TL, Zuccolo J, Sanyal R, Luider JM, Auer-Grzesiak IA, Mansoor A, Deans JP (2010) Quantification of CD20 mRNA and protein levels in chronic lymphocytic leukemia suggests a post-transcriptional defect. Leuk Res 34: 1670-1673.

Spalenza V, Girolami F, Bevilacqua C, Riondato F, Rasero R, Nebbia C, Sacchi P, Martin P (2011) Identification of internal control genes for quantitative expression analysis by real-time PCR in bovine peripheral lymphocytes. Vet J 189: 278-283.

Stachura A, Kaczmarczyk E, Bojarojć-Nosowicz B (2013) Sequence analysis of the regulatory region of the TNF-RII gene in Polish Holstein-Friesian cows. Genet Mol Res 12: 1028-1034.

Stark AM, Pfannenschmidt S, Tscheslog H, Maass N, Rösel F, Mehdorn HM, Held-Feindt J (2006) Reduced mRNA and protein expression of BCL-2 versus decreased mRNA and increased protein expression of BAX in breast cancer brain metastases: a real-time PCR and immunohistochemical evaluation. Neurol Res 28: 787-793.

Tartaglia LA, Goeddel DV, Reynolds C, Figari IS, Weber RF, Fendly BM, Palladino MA Jr. (1993) Stimulation of human T-cell proliferation by specific activation of the $75-\mathrm{kDa}$ tumor necrosis factor receptor. J Immunol 151: 4637-4641.

Tian Q, Stepaniants SB, Mao M, Weng L, Feetham MC, Doyle MJ, Yi EC, Dai H, Thorsson V, Eng J, Goodlett D, Berger JP, Gunter B, Linseley PS, Stoughton RB, Aebersold R, Collins SJ, Hanlon WA, Hood LE (2004) Integrated genomic and proteomic analyses of gene expression in Mammalian cells. Mol Cell Proteomics 3: 960-969.

Tsukada S, Tanaka Y, Maegawa H, Kashiwagi A, Kawamori $\mathrm{R}$, Maeda $\mathrm{S}$ (2006) Intronic polymorphisms within TFAP2B regulate transcriptional activity and affect adipocytokine gene expression in differentiated adipocytes. Mol Endocrinol 20: 1104-1111.

Tsukasaki K, Miller CW, Kubota T, Takeuchi S, Fujimoto T, Ikeda S, Tomonaga M, Koeffler HP (2001) Tumor necrosis factor alpha polymorphism associated with increased susceptibility to development of adult T-cell leukemia/lymphoma in human T-lymphotropic virus type 1 carriers. Cancer Res 61: 3770-3774.

Yang YC, Hsu TY, Lin RH, Su IJ, Chen JY, Yang CS (2002) Resistance to tumor necrosis factor-alpha-induced apoptosis in human T-lymphotropic virus type I-infected $\mathrm{T}$ cell lines. AIDS Res Hum Retroviruses 18: 207-212.

Yudin NS, Vasil'eva LA, Kobzev VF, Kuznetsova TN, Ignatieva EV, Oshchepkov DY, Voevoda MI, Romaschenko AG (2006) Association study of SNP of the TNF-alpha gene with bovine leukosis and evaluation of its functional significance. Comp and evolutionary genomics and proteomics, BGRS 2006: 245-248. 